\title{
The Library's Quality Management System and Quality Assurance in Higher Education: A Lesson from Southeast Emerging Educational Hub
}

\author{
Che Azlan Taib, Ari Warokka and Haim Hilman \\ College of Business - UUM, Malaysia
}

\begin{abstract}
As one of the national vision 2020's implementation programs, the establishment of a national Quality Assurance system focusing on the quality of the programs offered in terms of the general criteria of the structure and process of higher education is timely. In relating to the program, this paper aims to explore the efforts and other issues associated with the development and implementation of quality assurance in higher education due to its role as a service organization, which is required to enhance their quality of services. One of the important pillars determining the quality of higher-education service delivery is the library's quality management system. By using 46 public universities' libraries as the main sample, this study tested three hypotheses that are related to the nature of quality management practices by individual construct, as well as by aggregation value, and to what extent the difference to the numbers of staff and the type of organization will influence the quality management practices. We employed mean value and oneway analysis ANOVA as the research method to solve the questions. The validity of the constructs is measured using factor analysis, and its reliability is measured by Cronbach's alpha. Our study results revealed that the study sample perceived those constructs were important to maintain service quality to its customer. The study also informs that the number of staff and the type of organization do not influence at all on the library's quality management system. In other words, the awareness and spirit to play an important role in achieving excellent service to its customer is the main platform over the number of staff and the type of organization.
\end{abstract}

Key Words : Higher Education, Quality Assurance, Quality Management Practices.

\section{Introduction}

Since the establishment of the University of Malaya in 1959, it has become the starting point for the development of higher education in Malaysia (Morshidi Sirat, 2010), which at the same time, it has escalated also the rapid changes in the education industry and its related industry. Therefore, the educational system has gone through many reviews, in particular, the education policies.
This is because the government recognizes that education is a strategic tool that can play a significant role in the nation development. In particular, the Malaysian government has targeted by the year of 2020; Malaysia has to achieve a "developed nation" status.

To ensure this honourable vision is achievable, the role of education is obviously important. This vision required increasing

Copyright (C) 2012 Che Azlan Taib, Ari Warokka and Haim Hilman. This is an open access article distributed under the Creative Commons Attribution License unported 3.0, which permits unrestricted use, distribution, and reproduction in any medium, provided that original work is properly cited. Contact author: Che Azlan Taib E-mail: azlan@uum.edu.my 
access to higher education. Therefore, in the Ninth Malaysia Plan (2006-2010), the government has advocated the development of aworld-class human resources. Hence, the higher education must be strengthened and continuously empowered to be more effective and productive in the effort of creating a sustainable and knowledge-based human resources.

Higher education institutions are complex systems. The term of 'higher education' covers all post-secondary educations leading to the award of certificates, diplomas, and degrees (Wilkinson and Ishak Yussof, 2005). It interacts with the institutions around them, namely, with the existing political, economic, cultural and social systems (Sen, 2008). Higher institutions also interact with internal systems. They can be composed of physical and virtual environments, as well as a social environment, facilitating both interaction and individual privacy in learning processes. A physical learning environment is needed to obtain information and to study and for this important prerequisite facility, the library, as the knowledge hub of the university, should be centrally located for information gathering, with many terminals, multimedia workstations and connections to foreign information networks (Gersberg and Nenonen, 2007).

\section{Quality Assurance in Library}

According to Arora (2009), library is the 'heart' of the academic setup. Tayabas (1983) talked the same language as Arora. She mentioned that ".. the library at the center stage vis-a-vis the functions of the university: teaching, research and extension. To all these functions, the library and its services must be responsive. No academic development will occur out of teaching, research, and extension, whether collectively or individually, without the all-important supports of the library." Therefore, the library's role is very important and to be a good library in terms of efficiently resources management. It is highly recommended to control their quality of services.

In addition, changes in the field of higher education, including libraries are no longer tied to domestic factors, yet they are also affected by external factors, such as information technology, globalization, internationalization, and the global business in higher education. This matter requires the library to search for a center stage on how to be a competitive organization in terms of library management. This is applied in both the public and private sectors. Libraries are service organizations and as such. They exist in dynamic environments where supervision of the users seems to become evermore difficult to meet. Thus, the library, as a service provider, is not only focusing on the quality of service but also on the ability to move forward and adapt to the management of quality. It must meet the expectations of customers who govern the survival of an organization. To meet these challenges, it is recommended that the organization should apply certain quality management system or enforce on a quality assurance.

To develop this effort, organizations can use varied approaches. Generally, quality assurance is known as a systematic method or process to monitor and evaluate a service or product. Quality assurance is also recognized as all those planned and systematic action, such as policies, attitudes, action, and procedures that are necessary to provide adequate confidence that quality is being maintained and enhanced, and product/service meets the specified quality standard. ISO 9000, as international standard used by worldwide companies, is used to ensure that their quality assurance system is in place and effective. Conformances to ISO 9000 standards bring the guarantee that organization delivers qualified products and services. It means that organization management plays the important role in deciding the quality assurance policies and objectives. Therefore, once this policy and objective are in place, it 
can be said that the quality assurance procedures have been implemented. To evaluate the conformance and performance of an organization in applying the quality assurance, an external assessor will examine the company's quality assurance system to make sure it complies with ISO 9000.

Balague and Saarti (2008) also suggested that ISO 9001 is one of the possible ways to manage quality in an organization, which is emphasizing the continuing improvement of services, or a process oriented. Other studies had suggested the same approach. For example, Karapetrovic (1998: 109) stated:

"While emerging of communication technologies undoubtedly show that the world of education is facing rapid changes. The exclusive local university markets will soon cease to exist, and schools will have to both think and act globally in order to survive. So, how will universities assure prospective students and their future employers internationally of the quality of education provided? Many organizations have found a part of the answer to these problems in the introduction of internationally accepted generic standards for quality assurance from the ISO 9000 series. This would provide confidence to employers, students and the general public that their requirements for quality education and research are met, and would make systematic quality efforts visible"

Those statements propose that ISO 9000 could become a quality control tool, as well as a solution to meet customers' expectation and requirements. ISO has published specific guidelines for organizations in the education sector wishing to get benefits from the implementation of ISO 9001:2000. This quality system also is being internationally accepted, and ISO 9001: 2000 will certify the organizations' quality management systems and procedures. The ISO 9000 quality system provides a guideline for service organization to establish and implement a quality system, such as an educational institution. However, in Malaysia, the education sector is relatively lagged to adopt the ISO 9000 verification. To advocate this encouragement, the government specifically published a circular called "Public Management Act No. 2/1996: A Guideline to Apply MS ISO 9000 on Public Service" as enforcement to achieve this target.

\section{Research Question}

Prior studies have found various benefits that can be obtained by the implementations of ISO 9000 in the library. Mola (2007) found that there are five potential benefits that could be attained from ISO 9000, such as, a continuous improvement process, the decision making-based on data, the definition of responsibilities, the standardization of procedures, and a welldocumentation process. Meanwhile, the other benefits are empowering the skills of human resources, covering the international requirements, improving the staff morale, bringing a higher professional recognition, and helping carrying out an important introspection. Kaur (2007) also reported similar findings. She concluded that ISO 9000 benefits to the organizations' cultural changes and attitudinal shift of the staffs toward business-oriented values. Cultural and attitudinal shift makes staffs become more sensitive to quality-related issues in day-to-day work processes and thus. This shift enables organizations to be better operated in terms of user satisfaction.

According to American Library Association (2000), ervice becomes the core value of librarianship. Nejati and Nejati (2008) proposed that the quality of library service can be seen as the relating media to the fitness of a service to its intended purpose or use, subject to the expectations of the customer or user. Dabas (2008) suggested 3 As to define quality in libraries. They are: (i)accessibility - standing for both building and equipment and staff, which are including the ease, convenience, comfort, excitement and interest in using the printed, electronic and online information resources; (ii) 
availability - is the proportion of documents made available to users on request - it implies physical availability of all the resources of the libraries; and (iii) applicability - the accessibility and availability of library resources enhance the applicability of resources.

Therefore, it is important to find what the basic platform of Malaysian universities' library is to asses its quality performance and how to measure it by using certain constructs and the influencing factors. This study aims to find the nature of quality management practices by individual constructs, as well as by aggregation value. It also tries to provide empirical findings of to what extent the difference in the numbers of staff will influence the nature of the overall management practices. Finally, this study will investigate whether the type of organization will influence the quality management practices or not. Our study will contribute to this knowledge field by examining the relationship between ISO 9000 and quality performance of universities' libraries, which is rarely done previously in Southeast Asian developing countries. Most of the studies in the field are focused on analyzing this relationship for North American or European universities' libraries. Thus, a relevant contribution of this present work is that it reveals new insights of a sample of Southeast Asian universities' libraries for the empirical research.

\section{Literature Review}

Prior studies reveal that ISO 9000 plays an important influence on creating excellent service quality, such as for university library. Praditteera (2001) found 14 benefits of ISO 9000 in academic libraries in Thailand, such as, the enhanced accountability of parent institution; the improvement of good image and better practice has led to the improvement of library services; the improved library management control; the enhanced continuing quality management; the increased operational efficiency and productivity; the improved documentation; the increased in perceived quality of library services by customers; the increased library customer satisfaction; the reduced operating costs; the improved management of library resources; the improved library staff morale and attitudes; the improved effectiveness in teamwork; a better communication process among library staffs; and the improved library customers' perception on library quality management.

ISO 9000 also benefits in terms of administrative processes. The continually improvement principle in MS ISO 9001:2000 improves the ability of an organization to react quickly to opportunities and performance advantage (Kaur, Mohamad and George, 2006; Kaur, 2007). In terms of effective communication between the library and the parent organization, the QMS ISO 9001:2000 had really improved the library's internal communication and eliminated any possible misunderstanding because it had clarified the responsibilities and authorities of each attached post (Kaur, 2007). On the issue of job satisfaction and morale of the library staffs, Kiran (2007) found that the QMS ISO 9001:2000 had certainly increased the staffs' morale performance and job satisfaction beyond the expectation

Meanwhile according to Gupta (2000), s a service profession, library services are the accesses to books and information, such as advice and assistance that the library staffs provide to the users. However, what does service quality means? According to Oldman and Wills (1977), e concept of service quality was defined as the difference between library users' expectations and perceptions of service performance.

\section{Challenging of Quality Assurance in Library Services in Malaysia}

Quality has been defined in many different ways, and it forms a complex and subjective concept. According to The Quality Assurancy Agency for Higher Education of United Kingdom (2011), quality assurance in higher 
education is the total of systems resources and information devoted to maintain and improve the quality and standards of learning, scholarship and research, and students learning experience. According to Lawrence (2000), quality management is the aspect of the overall management function that determines and implements the quality policy, requires the commitment of top management including strategic planning, allocation of resources and other systematic activities for quality, such as quality planning, operations and evaluations. Therefore, quality management consists of four main constructs - quality planning, quality control, quality assurance, and quality improvement, whereby it focuses not only on product/service quality, but also on how to achieve it. Moreover, quality management uses quality assurance and control of processes to achieve the consistent quality. Quality assurance also includes those planned and systematic actions that are necessary to provide adequate confidence that a facility, structure, system, or component will perform satisfactorily and safety (Tripathi, 2009).

On the other point of view, some quality measurements of the product-based organizations may be referred to organizational profit. Therefore, an excellent service and satisfied customers mean bigger profits; poor service can be reflected by the lost of revenue (Nejati and Nejati, 2008). However, this concept is not for the library because it is not the profit organization. Furthermore, in the context of the library's service, the number of increasing satisfied customers may not be translated into monetary unit profit, but they do mean a highly regarded and valued library service (Pinder and Melling, 1996).

The fast-growing number of higher institutions in Malaysia has created certain challenging issues in higher education governance. In particular, the government has set higher education institutions in the Ninth Malaysia Plan as one of the key drivers to achieve the status of developed country by the year 2020 , which it means the quality of those institution is the main government's concern in order to build qualified human resources. The Malaysian government has launched a policy to open the Malaysian higher education sector for foreign universities to establish their affiliated universities or off-campuses in Malaysia. Therefore, this policy has pushed Malaysian higher education institutions to work in a competitive market. The demand for high quality service is coming out as a single critical factor due to this global market concept, which occasionally a user's needs has to be considered and the are unpredictable. Therefore, the organization should deal with its service quality management carefully in an intensified competition. Then, the concept of quality assurance, which is defined in prior studies, or quality management is the solution of this issue.

By defintion, quality assurance or quality management is about what the organization has to fulfill to the customers' quality requirements and other regulatory requirements, such as government regulations on product/service quality standards. Quality management increasingly presents in the life of the organization, and one of the options to manage it well is to apply the ISO 9001 (Mola, 2007) or TQM (Riggs, 1994). Quality management also relates to leadership and concerns with the strategy development, vision, and the effort of an organization to adapt perfectly in a changing environment (Pors and Johannsen, 2002). Particularly in the context of library service, quality management is about planning, organizing, and controlling the resources of the library, both human and non-human resources to achieve the goals and objectives (Riggs, 1997).

As international quality management standards and guidelines, the ISO 9000 becomes one of the sets of a series of quality management (QM) that assists an organization in developing, implementing, registering, and sustaining an appropriate 
quality management system that functions independently on the specific product and/or service (Westcott, 2006). It was originally published in 1987 by the International Organization for Standardization (ISO), and was revised in 1994 and again in 2000 (Goetsch and Davis, 2003). Its primary concern is "quality assurance," which refers to what an organization has to ensure the compliance of its product and service, whether it is consistent with the customer's requirements or not (Feng, Terziovski and Samson, 2008; Lin and Jang, 2008). In addition, it shall also give the possibilities to a librarian to assure its clients that the services offered are good quality services, within the limits of the budget (Taylor and Wilson, 1990).

\section{Methodology}

This empirical study compares the status of ISO 9001:2000 implementation towards quality management practices in five typically different library categories university library, teaching library, polytechnic library, community college library, and matriculation college library. The measurement is based on the survey method. The developed questionnaire consists of eight constructs of quality management practice. For each construct, close-ended and multiple-choice type questions were applied. Three to eight statements were used for the constructs based on a seven-point Likert scale response. Value 1 indicates that the statement is very low and value 7 indicates very high score. Samples were taken from public higher education institutions. One hundred and six questionnsires were sent out to the Malaysian public higher education libraries and 52 respondents responded by returning the questionnaire to us. From these figures, only 46 respondents are valid and used to further analysis.

Referring to the previous literatures, the developed questionnaire with consisting of eight conceptualize constructs were established (Taylor and Wilson, 1990;
Balague and Saarti, 2008; Tripathi, 2009). They are: (1) Customer Focus - it is conceptualized by commitment to satisfy customers, integration of customer satisfaction, knowledge of customer needs and expectations, usage of customer feedback, monitoring customer satisfaction, responsiveness to customer complaints, and the interaction with customers; (2) Leadership - it is conceptualized by understanding the needs, clear vision, target setting, convincing and eliminating curiousness; (3) Staff Involvement - it is conceptualized by staff involvement, continuous training empowerment, sharing, and conducive environment; (4) Process Approach - the organization output that is made up of a series of interacting processes; it involves a set of activities that use resources (people, machines, etc.) to transform inputs into outputs; (5) System approach - the activities of identifying, understanding and managing interrelated processes in a system way. This approach will lead the organization to be more effective and efficient in achieving its objectives; (6) Continuous Improvement it is the ongoing improvement that involves everyone (top management, managers, workers) and everything (process, method, tools, data and system). Thus the organization's overall performance will be a permanent objective; (7) Information and Data analysis - the information and analysis constructs are conceptualized by the availability of data, the timeliness of data and the usage of data, and (8) Supplier partnership - is conceptualized by the good supplier-organization relationship, supplier selection criteria, exchange of information, and supplier development.

\section{Scope of Study}

In general, a higher education institution comprises several departments, such as students affair department, academic affair department, bursary department, register department, and library department. These departments become supporting units to ensure the administration of any higher 
education process will run properly and adequately. At the moment, the record from the Malaysian Ministry of Higher Education shows that there are more than 1000 higher education institutions (public and privateowned) are operating and delivering higher education services. Due to some limitations, this study focuses only on the public higher education institutions and in particular, it pays attention to the public academic libraries.

\section{Realibility Tests}

The questionnaire's internal consistency will be tested by its realibility coefficient. In this study, Cronbach's alpha was used as the intrument's consistency measurement. The instrument realibility concerns to the extent of which instrument is reliable when different people are tested by that instrument in the different occasions (Nunnally, 1978). The higher values indicate the higher realibility. The realibility value test for this study was performed separately for each construct. Table 1 shows the Cronbach's alpha of each construct. The realibility value for each construct in this study is more than 0.7 , which is the minimum recommended value (Nunnally, 1978).

\section{Respondents Background}

Totally 52 libraries were selected. Out of those libraries, the valid respondents are 46. For the library classification, the data of 46 respondents (academic libraries) reveals that $17 \quad(36.9 \%)$ were from university libraries, 15 (32.6\%) were from higher education institutes, 10 (21.7\%) were from polytechnic colleges, 3 (6.5\%) from matriculation libraries, and one $(2.2 \%)$ was from community college library. The targeted respondent in this study to answer the questionnaire is the person is in charge to manage the quality system or the head of the library. The data also reveal that deputy of chiefs libraries become the majority of respondents (10), followed by the chief directors (8). The next top respondents are the chiefs' of librarians and the heads of the resource centers. They are equal to seven people per each category. Librarians became the top three from the last, and then the chiefs of libraries and the assistant officers followed it. They are 6, 5, and 1, respectively. The number of library staffs measures the size of the libraries. Nearly $59 \%$ of the respondents in our study are from the libraries with staffs less than 27 people. The rest respondents are the libraries with the number of staffs' ranges are from 10 to 30 or more than 50 staffs. For the number of users, most libraries have 1001 to 5000 users or more than 5000 users. For the length of time of the ISO implementation in the libraries, 18 libraries have already implemented the ISO as their quality system from 1 to 3 years and 16 libraries have used it within 4 to 6 years.

\section{Findings and Discussion}

To answer the objective 1 , the mean values were calculated. The objectives 2 and 3 were tested by using the one-way analysis of variance (ANOVA) statistical method. This statistical technique was introduced by R.A. Fisher in the 1920s, and its basic component is the sum of squares (Palaniswamy and Palaniswamy, 2006). In the one-way ANOVA, the data were sub-divided into groups (number of staffs) based on a single classification factor (Average of Overall QMP Level). It is used to test the mean of relationship between more than two independent variables with one dependent variable. We tested the null hypothesis, whereby there is no a significantly difference between the groups' mean scores ( $\mathrm{Ho}$ ) and there is a significantly difference between the groups' mean scores (Ha).

a. Objective 1 : To test the nature of the quality management practices' implementation - by individual construct as well as by aggregation value.

In this study, the mean values of all items (for a particular construct) or all the constructs (as aggregation value) were used to measure the first objective. It seems that 
the implementation of quality management practices in higher academic libraries overal is a 6.0 level. The results were shown in Table 1. It means that Malaysian universities' libraries have implemented the basic constructs of quality management system that are adapted from ISO 9001:2000. Those universities' libraries believe that they play important role in building and maintaining overall university's quality. By giving customer focus variable with the highest score (6.2), those libraries are fully aware that the main ingredient of successful-university determining components lies on the satisfied students or users. To achieve qualified services, those libraries believe that leadership and information data and analysis are the main supporting factors, which are represented by score 6.1 averagely. In other words, librarians become a vital factor in creating conducive environment that supports the qualified service delivery. At the same time, the availability of appropriate and up-todate infrastructure is considered as sine qua non condition to facilitate easily the expected service.

Table 1: Mean, Standard Deviation, and Reliability

\begin{tabular}{|l|c|c|c|c|}
\hline \multicolumn{1}{|c|}{ Variable } & No. of Items & Mean & SD & Reliability \\
\hline Customer Focus & 6 & 6.2 & 0.51 & 0.811 \\
\hline Leadership & 8 & 6.1 & 0.58 & 0.912 \\
\hline People Involvement & 6 & 6.0 & 0.57 & 0.898 \\
\hline Process Approach & 5 & 6.0 & 0.66 & 0.939 \\
\hline System Approach & 5 & 6.0 & 0.72 & 0.950 \\
\hline Continuous Improvement & 5 & 6.0 & 0.70 & 0.929 \\
\hline Information and Data Analysis & 3 & 6.1 & 0.71 & 0.903 \\
\hline Supplier Relationship & 6 & 5.9 & 0.61 & 0.896 \\
\hline Average of Overall QMPs & 8 & 6.0 & 0.55 & 0.952 \\
\hline
\end{tabular}

b. Objective 2 : To what extent the difference in the number of staffs will influence the nature of the overall quality management practices.

The one-way analysis of variance (ANOVA) was used to test whether the difference existed between the number of library staffs and quality management practices or not. We divided the groups of number of staffs into four groups - staffs less than 10 people, 10 to 30 people, 31 to 50 people, and more than 50 people. There were no significantly differences between the two groups (number of staffs and quality management practices). The analysis yielded an $\mathrm{F}$ value of $1.672(\mathrm{p}=.188)$ as reported in Table 2 . It means that the number of staffs does not hinder those libraries to perform quality management practices. It implicitly informs us that the Malaysian government policy through Public Management Act No. 2/1996: Guideline to Apply MS ISO 9000 on Public Service has successfully been implemented in those libraries. This policy has created good awareness on qualified service delivery, especially in the context of building qualified higher education institutions.

Table 2: ANOVA Test

\begin{tabular}{|c|c|c|c|c|c|}
\hline & $\begin{array}{c}\text { Sum of } \\
\text { Squares }\end{array}$ & $\mathrm{df}$ & $\begin{array}{c}\text { Mean } \\
\text { Square }\end{array}$ & $\mathrm{F}$ & Sig. \\
\hline Between Groups & 1.460 & 3 & .487 & 1.672 & .188 \\
\hline Within Groups & 12.231 & 42 & .291 & & \\
\hline Total & 13.692 & 45 & & & \\
\hline
\end{tabular}


c. Objective 3: To what extent the differences of organization type are influencing the nature of the overall quality management practices.

ANOVA was used to explore the relationship of organization types and quality management practices. The groups are divided into five categories, i.e. university, education institute, polytechnic, community college, and matriculation college. There were no significantly differences between the two groups, i.e. the difference type of organization and quality management practices. The analysis yielded an $\mathrm{F}$ value of $1.512(\mathrm{p}=.216)$ as reported in Table 3. This result reveals that the organization type does not deter those libraries to implement quality management practices. This striking finding can be explained from the point of statistical view. Due to the relatively small sample, an ANOVA analysis with 2 or 3 groups for a total sample size of about 45 respondents will only reveal statistically significance if the differences are fairly large. However, in the perspective of managerial practices, as a regulation, Public Management Act No. 2/1996 has become an obligatory practice that any kind public institutions should follow it and apply ISO 9001:2001 as the guidance for their qualified service delivery. This finding is interesting when we study this event in context of Malaysia, a developing country that is going to be a developed country in 2020. It informs us how serious Malaysian government is building its higher education's quality and facilitating it by giving a right platform of quality management.

Table 3: ANOVA

\begin{tabular}{|l|r|r|r|r|r|}
\hline & $\begin{array}{c}\text { Sum of } \\
\text { Squares }\end{array}$ & \multicolumn{1}{c|}{$\mathrm{df}$} & \multicolumn{1}{c|}{$\begin{array}{c}\text { Mean } \\
\text { Square }\end{array}$} & \multicolumn{1}{c|}{$\mathrm{F}$} & Sig. \\
\hline $\begin{array}{l}\text { Between } \\
\text { Groups }\end{array}$ & 1.760 & 4 & .440 & 1.512 & .216 \\
\hline Within Groups & 11.931 & 41 & .291 & & \\
\hline Total & 13.692 & 45 & & & \\
\hline
\end{tabular}

\section{Conclusion and Recommendation}

The study explores the general status of the Quality Management Practices in public higher education institutions in Malaysia. This study is considered as a good step to evaluate the status of quality practices towards higher quality assurance in Malaysia, i.e. an implementation of quality management principles. The Malaysian universities' libraries have adopted the quality management practices as an effort to deliver qualified service, by putting customer focus, leadership, and information data and analysis as the main factors. At the same time, due to the sample size limitations or statistical constraints, it also reveals that the size of libraries and type of organization do not influence at all the performance of those libraries in implementing and delivering quality management practices.

The study explicitly reveals that the quality of higher education services is being given serious intention by the goverment. Currently the quality assurance of higher education is controled by the Quality Assurance Agency for Higher Education, well-known as Malaysia Qualification Agency (MQA). Established in 2007, the main role is to implement the Malaysian Qualification Framework (MQF) as a basis for quality assurance of Higher Education and as a reference point for the criteria and standard for national qualification. In short, the MQF is the Malaysian government declaration on its higher education qualifications and the 
quality management-related policies to its education system.

Since the study evaluates the basis status of public higher education institutions' quality achievement, particularly in a certain quality management practice area, further studies should be performed to evaluate the overall status of quality assurance in public and private-owned higher education institutions. This study has contributed to the body of knowledge by giving the effectiveness measurement of the MQF implementation. The further studies will be also important as the benchmark process to evaluate the performance of MQF establishment after several periods of years.

\section{References}

American Library Association (2000). 'Standards for College Libraries. College and Research Libraries News,' (Final Version Approved January), 175-82.

Arora, J. (2009). "Library 2.0: Innovation Technology for Building Libraries Tomorrow," Edited by Kataria, S., Et Al. (2008). International Symposium on Emerging Trends and Technologies in Libraries and Information Services (2008). Jaypee Institute of Information Technology University, Noida (Up), India.). New Delhi: Kbd Publications.

Balague, N. \& Saarti, J. (2008). "Benchmarking Quality Systems in Two European Academic Libraries," Library Management, 30(4/5), 227-239.

Dabas, K. C. (2008). 'Quality Management in Libraries,' New Delhi: Ess Ess Publications.

Feng, M., Terziovski, M. \& Samson, D. (2008). "Relationship of Iso 9001:2000 Quality System Certification with Operational and Business Performance: A Survey in Australia and New Zealand-Based Manufacturing and Service Companies," Journal of Manufacturing Technology Management, 19(1), 22-37.
Gersberg, N. \& Nenonen, S. (2007). 'The Higher Education Learning Environment: A Finnish Technology Hub,' Edited by Higher Education Facilities: Issues and Trends. Oecd.

Goetsch, D. L. \& Davis, S. B. (2003). Quality Management: Introduction to Total Quality Management for Production, Processing and Services. New Jersey: Prentice Hall.

Karapetrovic, S., Rajamani, D. \& Willborn, W. (1998). "Iso 9001 Quality System: An Interpretation for the University," International Journal of Engineering Education, 14(2): 105-117.

Kataria, S., Nigam, B. S. \& Shukla, R. K. (2008). International Symposium on Emerging Trends and Technologies in Libraries and Information Services. Jaypee Institute of Information Technology University, Noida (Up), India.). New Delhi: Kbd Publications.

Kaur, K. (2007). Ms Iso 9001:2000 Implementation in Malaysian Academic Libraries. Building an Infirmation Society for All. Zainab, A. N. Petaling Jaya, University Malaya: 491.

Kaur, K., Mohamad, P. \& George, S. (2006). "Quality Management Service at the University of Malaya Library," Library Management, 27: 249-256.

Lawrence, W. H. T. (2000). "Quality Management Theory and Practice: Some Observations of Practices in Australian Academic Libraries," Library Management, 21(7), 349-356.

Lin, C.- I. \& Jang, W.- Y. (2008). "Successful Iso 9000 Implementation in Taiwan How Can We Achieve It, and What Does It Mean?," International Journal of Productivity and Performance Management, 57(8), 600-622.

Mola, N. B. (2007). 'The Use of Iso 9001 Quality Standard in Higher Education 
Institution Libraries,' Library Service, 11(3), 66-78.

Morshidi Sirat (2010). Introduction. Edited by Zailan Moris 50 Tahun Pembangunan Pendidikan Tinggi Di Malaysia (1957-2007) 50 Years Higher Education Development in Malaysia (1957-2007). Pulau Pinang: Penerbit Universiti Sains Malaysia.

Nejati, M. \& Nejati, M. (2008). "Service Quality at University of Tehran Central Library," Library Management, 29(6/7), 571582.

Nunnally, J. C. (1978). Psychometric Theory. New York: Mcgraw-Hill.

Oldman, C. \& Wills, G. (1977). 'The Beneficial Library,' Bradford: Mcb Books.

Palaniswamy, U. R. \& Palaniswamy, K. M. (2006). Handbook of Statistics for Teaching and Research in Plant and Crop Science. New York: Food Products Press.

Pinder, C. \& Melling, M. Eds. (1996). 'Providing Customer-Oriented Services in Academic Libraries,' London: Library Association Publishing.

Pors, N. O. \& Johannsen, C. G. (2002). "Job Satisfaction and Motivational Strategies among Library Directors," New Library World, 103(1177), 199-208.

Praditteera, M. (2001). Iso 9000 Implementation in Thai Academic Library. School of Education: University of Pittsburgh.

Riggs, D. E. (1994). 'TQM : Quality Improvement in New Clothes,' Disunting Oleh O'neil, R. M. Total Quality Management in Libraries: A Sourcebook. Englewood: Libraries Unlimited Inc.

Riggs, D. E. (1997). "What in Store for Academic Libraries - Leadership and Management Issues," The Journal of Academic Librarianship, 23(1), 1-8.
Sen, R. (2008). 'Higher Education System, Edited by Sen, R. Encyclopaedia of Higher Education: Higher Education In 21st Century. New Delhi: Crescent.

Tayabas, B. G. (1983). 'Academic Library: The Heart of the University,' Persidangan Pengarah/Ketua Perpustakaan Institusi Pengajian Tinggi Milik Pemerintah NegaraNegara Rantau Asean. Sabah, Y. Mini Teater, Bangunan Ibu Pejabat Yayasan Sabah, Yayasan Sabah.

Taylor, M. H. \& Wilson, T. (1990). Q. A. Quality Assurance in Libraries: The Health Care Sector: A Collection of Studies, Ottawa: Canadian Library Association.

The Quality Assurancy Agency for Higher Education (2011). Qaa Assuring Standards and Improving Quality of Uk Higher Education. Accessed From: http://www.qaa.ac.uk/pages/default.aspx.

Tripathi, M. \& Jeevan, V. K. J. (2009). "Quality Assurance in Distance Learning Libraries," Quality Assurance in Education, 17(1), 45-60.

Westcott, R. T. (Ed). (2006). 'The Certified Manager of Quality/Organizational Excellence Handbook,' Milwaukee: Asq Quality Press.

Wilkinson, R. \& Yussof, I. (2005). "Public and Private Provision of Higher Education in Malaysia: A Comparative Analysis," Higher Education, 50(3), 361-386. 